\title{
Students' Linguistics Problem in Reading Comprehension
}

\author{
Sinta Frestisia ${ }^{1, *}$ Ratmanida $^{1}$ \\ ${ }^{1}$ Universitas Negeri Padang, Padang, Indonesia. \\ *Corresponding author. Email: sintaefrestisia14@ymail.com
}

\begin{abstract}
Reading English as foreign language is not easy for EFL students. The students have encountered different linguistic elements from their first language. This research aims to discuss students' linguistics problem in comprehending English text. This research was document analysis and the data were analyzed by researcher from some previous studies. As a result, the researcher found that there are some problems in student's linguistics competence; it influence on their process of comprehending a text. It also found the students have many problems in linguistics are caused by some factors. Moreover, students' linguistics problem in reading English text cannot be ignored because EFL students had much experience reading in their first language rather than foreign langauge.
\end{abstract}

\section{Keywords: Linguistic, linguistics problem, reading comprehension}

\section{INTRODUCTION}

In education field, reading is an activity that the students need to do all the times. By reading, the students can improve their understanding and help them to wide their insight. Reading is the basic skills and very benefit for students to access explanation and information of critical evaluation skills. In other word reading has a big impact to achieve better understanding in learning process [1].

Reading as a basic skill is also explained by Hung and Ngan [2] which explain that reading help students to improve their vocabulary, fluency, and it also help them in other skills. In finally, it helps them to learning and be master in their target language. For example in the process of learning English, reading has an important role in language learning development. Therefore, by reading English text it will help the students to enrich their vocabulary, acquiring grammar, and learn how to writing well [2].

In learning process, reading English is one of the subjects that students have learned since in Junior High School. In fact, reading in foreign language is not easy for students. It is supported by Hamra and Syatriana [3], they found there are some reasons of EFL students' difficulties. Those are the problem in vocabularies, lack knowledge of words, phrases, paragraphs, and pronunciation difficulties.

The finding is appropriate with Alderson's statement [4] that explain there are still many students are failed to read appropriately in foreign language, they are unable to understand what they read and they also read at slow rate. It is caused the students are not efficient and effective in foreign language and fail to transfer them.

In the same case, Jayanti [5] in her study explain about students' perception on their difficulties during reading English text. She finds that the students are difficult to answer the reading comprehension question section in English test.

Sanford [6] identified there are some factors that obstruct students in reading comprehension. The factors come from the students that have problem in phonemic awareness, the problem in the process of recognize sounds of letter and the problem in word recognition. It is also found by others research that explains about the factor that obstruct student to comprehend text. The factors that include are poor working memory, poor general knowledge, and lack of vocabulary [7]. In sum, it can be conclude that vocabulary knowledge is very important and affects in understanding reading comprehension.

In another research by Masduqi [8], he explained about the student's perception. He stated that the students feel boring and stressful in reading class. The students feel the English text is too long, they do not have enough vocabulary to understand the meaning of words and they lack of pre reading activities. Furthermore, reading in foreign language and reading in first language are different. In comprehending the text, 
the students have to consider language elements. In reading English, the students will find a number of different linguistic elements from their first language.

Linguistics elements are very important in learning language. Khansir \& Pakdel [9] explain that linguistics always allow the process of learning English language. They added that in the histories learning of English language, there were several hypotheses in the linguistics field in English instruction to motivate the students in learning English There are many varieties problems in linguistics that the students have while reading. The previous observers have been observed EFL students. Oakhill [10] identified three main problems in reading comprehension. The first, the comprehension problem is caused by the difficulties at single- word level. The second, the problem is caused by the difficulty in the syntactic and semantic analysis. The third, the problem is poor comprehend in making inferences from text, integrating ideas, and monitoring their own comprehension.

Then, Al-Beckry and Reddy in Kashim [18] argue that reading problems are caused by the lack concept of reading process, inadequate linguistic knowledge, and difficulties to different the spelling of English sound systems. In other words it can be said that reading problem is related to the problem in reading process and linguistics knowledge problem. Fromkin, Rodman, and Hyams [11] explain main aspect of linguistic knowledge; it is the knowledge about the system of sounds, structure, meanings, words, and how to putting them in sentence or text. They add that the linguistics problem in reading include semantic, lexical, and syntactical problems.

The other research [12] found that there are 72 respondents believe the reading English problems that they have are caused by language problem. The lack of linguistic competence affects on their process to comprehend English text. This research concludes that the reading problem is linguistic problem. There are some studies about linguistic problem that have been done. In summarized, the linguistic reading problems include phonology [13], semantic, syntactic structure [9], lexical and vocabulary [14].

a) Phonology

It knows as speech of sound in natural language. It is concerned with how speech sounds are organized in the mind and used to convey meaning. In reading, phonology is related for learning to read any alphabetic writing system. In a research by Renaldi, Stefani, and Gulo [15], they find that most of the phonological problems found were related to consonant sounds. It means in reading English the students have problem in how to read variety of consonant sounds.

b) Semantic

Semantic knows as linguistic field that study about the meaning of linguistic expressions. It supports by Lobner [16] that argue semantic is the study of linguistic meaning, either simple or complex, taken and isolation, it further accounts for the way utterance meaning. To understand the meaning, the students need to understand the meaning of words in the text. In fact, many of students have difficulties in meaning of words. It is caused by lack of vocabulary knowledge.

c) Syntactic

Syntactic problem can divide into two ways. First, the student's ability in understanding syntactic structure when they are spoken will be different when they are read. Second, some syntactic structure is more frequent in speech than in written form and it is unfamiliar when it find in print. In addition In addition, Chain [17] explained that syntactic awareness constitutes a metalinguistic skill and distinct from of sentence. Therefore, it concerns the ability to consider the structure rather than the meaning of a sentence.

d) Lexical

Lexical problem is related to the meaning of lexical words that involve lack of knowledge about derivations and word classes. It is supported by some research that has already demonstrated that readers' ability to understand what they read is strongly connected to their lexical knowledge [14].

e) Vocabulary

Vocabulary is one of most important skills that needed in teaching and learning a foreign language. However, there are many of students have problem in vocabulary. The inadequate of vocabulary knowledge has impact in understanding the text. When the students know more words, they will be more able to understand what they read. It is a strong connection between understanding the meaning of words and understanding their textbook or other reading materials.

In one site, the linguistics is closely related in students reading comprehension. To be able to comprehend English text, the student should have linguistic competence. 


\section{METHOD}

This research used a descriptive research design. The document analysis was used in this research. The data of this research were collected from the documents. The documents are journals that related to students' linguistics problem in reading. There are some journals that become the sources of data for this research, namely:

a. F. G. Jayanti [5] "Reading Difficulties: Comparison on Students and Teachers Perception.

b. A. H. Albashtawi, P. Jaganathan, and M. Singh [18] "Linguistic Knowledge Aspects in Academic Reading: Challenges and Deployed Strategies by English-Major Undergraduates at a Jordanian Institution of Higher Education.

\section{RESULTS \& DISCUSSION}

Related to the all researches above, the finding shows that there are some similarities and differences in the result. In the first journal it was found that vocabulary problem is the most difficulties that students have. This journal explains there are many students also have difficulties in syntactic and semantic analysis. It also explained that the students are difficult and feel confuse to understanding long sentence. Moreover, the result of this journals explain that the students are still have less knowledge about language,

In the second journal, it found that the most problem were related to student's incapacity to recognize the genre of text. It also explained that the students are not able to know the meaning of words, understanding of text structure, and guess the points of writer's view in the text. The students also found have difficulties in reading fluency knowing concluding sentence. Asassfeh et al [23] explain low linguistics competence obstruct them to understand the contextual clues to get the meaning of the text. Related to this problem, reading quickly can help the students to reach the meaning easily. Reading habit would help students to be more fluently in reading

The results of the study were similar to Mokhtari [23] that explain the limits vocabulary obstruct students to understand the meaning of text. Consequently, the large vocabulary knowledge is very important to help the students in improving their reading comprehension.

Next journal by Kashim \& Raisha [18], it shows the result of their research found the highest linguistics reading problem is in semantic. In specific, it was 34 of 42 students who have reading problem. They found the most of students still have low vocabulary competence. c. Khasim, Umar and Raisha, Siti [19] EFL Students' Reading Comprehension Problems: Linguistic and Non-linguistic Complexities. English Education Journal.

d. Atikah [20]; An Analysis of Student's Linguistics Problem in Reading Comprehension.

e. Hidayati [21]; The Analysis on Students' First Grade of SHS 1 Darussalam Aceh Besar.

f. Nurjannah [22] Students Difficulties in Reading Comprehension.

Furthermore, after collecting the data, the data were analyzed qualitatively. The data were identified in suitable data that can be presented in this research. The data were done by classifying the findings of all journals.

It is caused the students unable to understand the meaning of unfamiliar words. Next, the second biggest problem is syntactical problems. Overall, the result of their finding shows that it is $69 \%$ students have linguistic problems in reading English text. The score was 2.84 out of 4.They categorized the mean score that have been counted based the students' score is at difficult level. In this journal, it can be conclude the vocabulary is the most frequent problem that always be found in students reading comprehension Then, in the fourth study, Atikah [19] found some problems in student linguistics' problems in reading comprehension. The problems are in vocabulary, structure and in low spelling a. It can be known from the explanation in calculating. She finds there were $38.13 \%$ students had difficulties in vocabulary. And the, there were $48.33 \%$ students had difficulties in using structure, and there were $31.25 \%$ students had difficulties in spelling. It can be conclude that the most difficulties that made by students in this research is in using structure. It is different from the three journals that explain before which the problem is always related to the meaning and vocabulary.

Moreover, in the fifth study Hidayati [20], she noted that the students have some difficulties criteria. She found the student's problem is related to understanding the text. In calculating, she found that the students who have difficulties in answering main idea are $74 \%$. The students who have difficulties in making inferences are $56 \%$. The students who have difficulties in locating reference questions are $71 \%$. In this calculating, it can be known that the most problems that find in this study are the student's problem in finding the main idea. In addition, this study explains the factors that affect on student's problem in reading. It is explain that, most of 
students are failed and had problems because they have poor vocabulary knowledge, lack knowledge of grammar, and the problem to understand long sentence/ text.

Last, in the sixth journal Nurjannah [21], she reported that the problems come from vocabulary knowledge. She explains that, the students are difficult in vocabulary section because the students do not have rich vocabulary. The students have difficulties to memorize new words. The students are unable to differentiate the meaning of new words. They feel confuse because in English there are some words have similar meanings, and they feel confuse to use it. She explains the students are easily to forgotten the new words because they are rarely to use those words in their daily. Most of students like to use the words that they familiar rather than the new words that they get. It causes the language development is not improved and their vocabulary is limited.

Next, she found that the students have problem in finding the main idea. The students feel confused because they are unable to find the main sentences. In this problem, it can be caused by the students are inability to understanding the meaning of sentence. In addition, this problem is also caused by low frequency of reading, and the students are unable to catch the meaning of sentences.

\section{CONCLUSION}

To sum up, it can be conclude that linguist's competence has important role in reading English text. However, there are some factors that caused reading become difficult for students; phonology, syntactic, semantic, vocabulary knowledge, finding main ideas, making references, memorizing new words, difficulties in tenses, getting information, answering questions, lexical problem, and etc. The students have difficulties in reading comprehension because of their linguistic competence is still poor. Besides that, the other reason that caused the students are fail to read appropriately effectively in foreign language because they do not have enough much knowledge about native language reading skill, and it makes they are failed to transfer them. In other words, it can be said that the differences of linguistics elements between their first language and foreign language causes the EFL students be confused and get difficulties in reading English. It suggests for the students that to help them in comprehend English text well, they should improve their linguistic competence.

\section{ACKNOWLEDGMENT}

The writer expresses the deepest appreciation goes to her parents, sisters, brother and friends who have given supports, pray and motivation. Then, this study would have been possible without help of my advisor Dr. Ratmanida, M. Ed.,Tefl for her advice and guidance.

\section{REFERENCES}

[1] Yukselir, C. (2014). An Investigation into the Reading Strategy Use of EFL Prep-Class Students. Social and Behavioral Sciences Journal, 158, 65-72.

[2] Hung, D. M., \& Ngan, V. P. T. (2015). Investigating Reading Strategies Used by EFL Students at Dong Thap University. Asian Journal of Educational Research, 3(4), 10-20.

[3] Hamra, A., \& Syatriana, E. (2010). Developing A Model of Teaching Reading Comprehension for EF Students. TEFLIN Journal,21 (1), 27-40.

[4] Alderson, J. Charles, Assesing Reading. Cambrige: Cambridge University Press, 2000.

[5] F. G. Jayanti, "Reading Difficulties: Comparison on Students and Teachers Perception," Fourth Int. Semin. onEnglish Lang. Teach., pp. 296-301, 2016, [Online]. ejournal.unp.ac.id/index.php/selt/article/view/6 939.

[6] M. Smith, J. Turner, E. Sanford-Moore, and H. H. Koons, "The Lexile Framework for Reading: An Introduction to What It Is and How to Use It," in Pacific Rim Objective Measurement Symposium (PROMS) 2015 Conference Proceedings, 2016.

[7] M. Iqbal, M. Noor, F. Muhabat, and B. Kazemian, "Factors Responsible for Poor English Reading Comprehension at Secondary Level," SSRN Electron. J., 2015, doi: $10.2139 /$ ssrn.2602630.

[8] H. Masduqi, "Efl Reading in Indonesian Universities: Perspectives and Challenges in Cultural Contexts," J. Teach. Educ., vol. 03, no. 03, pp. 2165-6266, 2014, [Online]. Available: http://www.universitypublications.net/jte/0303/ pdf/V4G339.pdf.

[9] A. A. Khansir and F. Pakdel, "Place of 
Linguistics in English Language Teaching," Arab World English J., vol. 7, no. 3, pp. 373384, 2016, doi: 10.24093/awej/vol7no3.26.

[10] Oakhill, J. 1993. Children's Difficulties in Reading Comprehension. Educational Psychology Review 5(3)

[11] Fromkin, V., Rodman, R., \& Hyams, N. (2003). An Introduction to Language (7thed.).

Massachusetts: Heinle.

[12] I. R. Gloria Barus, "The Study And Analysis Of Reading Difficultes Of The Undergraduate Students," J. Ilm. Manaj. Bisnis Ukrida, vol. 9, no. 2, p. 96783, 2009.

[13] Al-Ajmi, S. A. (2003). Omani EFL students' perceptions of reading difficulties. Unpublished master's thesis. Sultan Qaboos University, Oman.

[14] Rahman, M.H. 2007. An Evaluation of the Teaching of Reading Skills of English in Bangladesh. Unpublished Thesis. Retrieved on April 10, 2016 from www.asian-efl .

[15] A. Renaldi, R. P. Stefani, and I. Gulö, "Phonological Difficulties Faced by Students in Learning English," Proc. Fourth Int. Semin. English Lang. Teach. (ISELT 4), no. May, pp. 97-100, 2016, doi:

10.13140/RG.2.1.2233.1763.

[16] Löbner, S. (2002). Understanding Semantics. London: Arnold.

[17] K. Cain, "Syntactic awareness and reading ability: Is there any evidence for a special relationship?," Appl. Psycholinguist., 2007, doi: 10.1017/S0142716407070361.

[18] A. H. Albashtawi, P. Jaganathan, and M. Singh, "Linguistic Knowledge Aspects in Academic Reading: Challenges and Deployed Strategies by English-Major Undergraduates at a Jordanian Institution of Higher Education," High. Educ. Stud., vol. 6, no. 3, p. 61, 2016, doi: 10.5539/hes.v6n3p61.

[19] Khasim, Umar and Raisha, Siti. 2017. EFL Students' Reading Comprehension Problems: Linguistic and Non-linguistic Complexities. English Education Journal (EEJ), 8(3), 308-321

[20] Atikah, Ikah. (2009). An Analysis on the Students' Linguistics Problems in Reading
Comprehension. Universities Syarif Hidayatullah. Jakarta. Unpublished thesis.

[21] D. Hidayati, "Students Difficulties in Reading Comprehension at The First Grade of SMAN 1 Darussalam Aceh Besar,” p. 15, 2018

[22] R. Laily, "The Analysis on Students' Difficulties in Doing Reading Comprehension Final Test," Metathesis J. English Lang. Lit. Teach., vol. 2, no. 2, p. 253, 2018, doi: 10.31002/metathesis.v2i2.958.

[23] S. M. Asassfeh, F. M. Khwaileh, Y. M. AlShaboul, and S. S. Alshboul, "Communicative Language Teaching in an EFL Context: Learners' Attitudes and Perceived Implementation," J. Lang. Teach. Res., 2012, doi: 10.4304/jltr.3.3.525-535. 